\title{
Katarina Zadnik
}

Akademija za glasbo, Univerza v Ljubljani

Academy of music, University of Ljubljana

\section{Primary Music School Education in Slovenia and Montenegro Osnovno glasbeno šolstvo v Sloveniji in Črni gori}

Prejeto: 13 . november 2018

Sprejeto: 1. marec 2019

Ključne besede: glasbena šola, Slovenija, Črna gora, zgodovinski razvoj, sodobni predmetniki

\section{IZVLEČEK}

Primerjava slovenskega in črnogorskega osnovnega glasbenega šolstva kaže raznolik zgodovinski razvoj. V slovenskem prostoru poteka sodobno izobraževanje 10 let, v črnogorskem prostoru 9 let. V slovensko glasbeno šolo se lahko vpišejo 5-letniki, v črnogorsko šolo 6-letniki. Oba predmetnika obsegata glasbenoteoretične in inštrumentalne predmete, slovenski koncept vključuje več inštrumentalnih področij.
Received: $13^{\text {th }}$ November 2018

Accepted: $1^{\text {st }}$ March 2019

Keywords: music school, Slovenia, Montenegro, historical development, contemporary curriculum

\section{ABSTRACT}

Comparison of primary music school education in Slovenia and Montenegro showed distinctive historical development. Contemporary education lasts for 10 years in Slovenia, 9 years in Montenegro. Enrolment in Slovene system is available for 5-year-olds, in Montenegro, for 6-year-olds. Curricula encompass music-theoretical and instrumental subjects, Slovene concept includes more instrumental areas.

\section{Introduction}

The entire vertical of the contemporary Slovene public music school education - from primary through secondary to higher level - is systemically well organised and regulated by law. With its long tradition, primary music education, carried out by primary music schools, is oriented towards identifying musical and dance talents among pre-school 
and primary school children, encouraging their artistic expression, developing musical abilities, skills and knowledge necessary to participate in various amateur musical groups and directing children into further music education at the secondary level. Positive effects of elementary music education in the pre-school and primary-school period are supported by numerous contemporary studies proving positive influence on holistic (musical) development. ${ }^{1}$ In the European territory, we can observe a variety of legal, systemic and organisational aspects of primary level music school education, as well as different didactic concepts and their integration in the national curricula. Contrary to Slovenia which has a quality music school system, in some European countries we can observe several contradictions in terms of legislation and organisation, as well as existence of national curricula for music schools. According to European Music School Union's statistical data (2015), some of their members, e.g. Estonia, France, Croatia, ${ }^{2}$ the Netherlands and Sweden, as well as some regions in Germany, Italy and Serbia do not have any regulated education at the level of primary music school. The 2015 data also show disparities in terms of elaboration of the curricula and existence of syllabi at the national level. In some European countries, e.g. Danmark, Estonia, some regions of Italy, Liehtenstein, the Netherlands, Norway, Sweden and Switzerland, education at the level of primary music schools is not set out by the national curricula ${ }^{3}$ which would gradually and systematically steer towards a process-oriented treatment of contents at all educational levels. ${ }^{4}$ Differences in the legal, systemic, organisational and curricular settings of elementary music schools stem from the past and present cultural, artistic, performing and social development of various European local, regional and national environments. The present paper focuses on the concept of contemporary music school education in Slovenia and Montenegro, two former Yugoslav republics. Even though the two countries used to pertain to a common geopolitical area, the development of their music education system differed considerably. From the second half of the $19^{\text {th }}$ century and until World War II, the Montenegrin system followed the Russian school, ${ }^{5}$ while, in the second half of 19th century until World War I, the Italian and German influences dominating Slovenian music in the past, thus slowly began to be replaced predominantly with Czech musicians who worked as music reproducers, composers, publicists and also as music teachers. Most of them gained their musical knowledge at the leading music institutions of Czech universities. Numerous

1 Barbara Smolej Fritz, "Razvoj vidikov glasbenih sposobnosti, ki jih meri Bentleyev test," Psihološka obzorja 9, št. 1 (2000): 92-95. Barbara Sicherl Kafol, Celostna glasbena vzgoja. Srce, um, telo (Ljubljana: Debora, 2001), 162-210.

Olga Denac, Glasba pri celostnem razvoju glasbene osebnosti (Ljubljana: Zavod RS za šolstvo, 2002), 98-108.

Katarina Zadnik, "Razvoj ritmičnega in melodičnega posluha pri 8-letnih učencih v glasbeni šoli," (Dok. dis., Univerza v Ljubljani, Akademija za glasbo, 2011), 10, 261-268.

Barbara Kopačin, "Medsebojna povezanost inteligentnosti, glasbenih aktivnosti in družinskega okolja pri devetošolcih," Revija za elementarno izobraževanje 7, št. 2 (2014): 82-85. http://www.pef.um.si/content/Zalozba/clanki_2014_letnik7\%20_stev_2/ REI\%207\%202\%20web\%20cl\%205.pdf.

2 Statistical data for 2010.

3 Analysis shows that music schools system lacks regulatory and national curriculum basis in Estonia, Ireland, Italy, the Netherlands and Sweden.

4 "Statistical information about the European Music School Union," EMU 2015, accessed October 25, 2018, http://www. musicschoolunion.eu/wp-content/uploads/2017/09/EMU-Statistics-2015-08.09.2017.pdf.

5 Jelena Bogojević Martinović, "Views on the Elementary Music Education in Montenegro and Slovenia," Javno glasbeno šolstvo na Slovenskem. Pogledi ob 200-letnici, 25 (2016): 306. 
Czech musicians, who were active in the field of music education, applied their highly applicable musical and didactic knowledge in to learning process within the new established of the most important music institutions in Slovene territory. ${ }^{6}$

After World War II, during the period of the common state, there were some influences by the Croatian and Serbian music educationalists, and in Montenegro we can also trace influences by some Slovene music educationalists who worked there. Influences of the Slovene systemic organisation of primary music schools and musiceducation doctrine can still be found in Montenegro today. The shift from an eight- to a nine-year primary school in Slovenia was followed in Montenegro as a quality sample model of a primary school system reform. ${ }^{7}$ The process of the first curricular reform in the Montenegrin general school system, introduced after Montenegro gained its independence in $2006,{ }^{8}$ was carried out with professional support of and in international cooperation with the Republic of Slovenia which steered the structure and content of the changes made in the field of primary school education. As a result of this cooperation, the Slovene music didactics concept, with activity-based approach as its fundamental orientation, is reflected in the Montenegrin national curriculum for the subject called Music Culture (Muzička kultura) in their nine-year primary school.

The present paper focuses on and compares the contemporary Slovene and Montenegrin concepts of music education in primary music schools, comparing also their courses of development from the $19^{\text {th }}$ century to the present day. It gives an overview of similarities and differences in the educational structure of the two systems. It compares an enrolment conditions at the preschool and primary level, duration of education and structure of curricula in both countries, with emphasis on areas of instrumental and music-theoretical subjects. The paper is devised on theoretical and historical backgrounds, and it is based on descriptive, analytical, comparative methodological research approach.

\section{Development of Music School Education: Comparison between Slovenia and Montenegro}

The modern music school systems have their roots in the traditions of individual countries' musical, cultural and artistic tradition, as well as societal and social circumstances and needs at the national, regional and local level. In order to understand the current state of music schools, it is necessary to look back into the course of events and tendencies which (co-)influenced the establishment of music institutions as important milestones in the development of music education. The system of music schools in Slovenia has got a rich, 200-year-long tradition. The origins of institutionalised music education go back to the beginning of the $19^{\text {th }}$ century, more precisely to the year 1816 when the first

6 Jernej Weiss, “'Slovenian music history' or 'History of music in Slovenia'," Muzikološki zbornik 45, št. 1 (2009):78, 79. http://www.dlib.si/?URN=URN:NBN:SI:DOC-V3DCAODM.

7 Bogojević Martinovič, "Views," 309.

8 Until 2006 Montenegro, together with Serbia, was part of the Federal Republic of Yugoslavia. "Principles and general objectives of education. Montenegro," World Data on Education 6th edition (2006/07), accessed October 25, 2018.

http://www.ibe.unesco.org/Countries/WDE/2006/CENTRAL_and_EASTERN_EUROPE/Montenegro/Montenegro.pdf. 
public music school was established in Ljubljana in the framework of a primary school then called normalka. In 1875 the music school became part of the German Philharmonic Society and this enhanced the tendencies and endeavours to establish a music society which would promote the development of Slovene music creativity and performance. These initiatives matured in 1872 with the establishment of the Slovene music society Glasbena matica in Ljubljana. The society encouraged the development of Slovene music education, creativity and performance, it was in charge of collecting folk songs, music publishing, libraries and schools. Since its very beginning, the society was aware of the importance of music education at all levels. Thus, in 1882, the Glasbena matica society established a lower music school in Ljubljana. Following its example, music schools began emerging in other Slovene towns as well. ${ }^{9}$ As we have already mentioned, in the second half of the 19th century numerous Czech musicians left their traces in the field of music education in the Slovene territory. ${ }^{10}$ Most of them were active at the music school Glasbena matica in Ljubljana and other Slovene towns and they also collaborated with other institutions ${ }^{11}$ that offered music-education programmes. ${ }^{12}$

After years of efforts and hard work, the Glasbena matica Conservatory was founded in 1919. It was a secondary-level education institution which was nationalised in 1926 in the then Kingdom of Serbs, Croats and Slovenes, thus becoming the first Yugoslav conservatory. It laid the foundation for a music academy which was established just before World War II, in 1939. Up until World War II, music education was also provided by societies and private music schools, the latter contributing significantly to the development of music education in the Slovene territory..$^{13}$ After World War II, in 1950's, state music schools were increasingly being opened, following the model of Eastern European countries and the Soviet Union (today's Russia), while the development of private music schools was brought to a halt, in line with the social order and political regime of the time. With Slovene independence in 1991, the network of public as well as private music schools began to spread. Currently, there are 54 public and 15 private music schools. ${ }^{14}$

The beginnings of music education in Montenegro go back to the first half of the $19^{\text {th }}$ century, when a military band and the first singing society Jedinstvo (1839) were established in Boka Kotorska, a territory which at the time was part of the Habsburg

9 Nataša Cigoj Krstulović, Zgodovina, spomin, dediščina: ljubljanska Glasbena matica do konca druge svetovne vojne (Ljubljana: Založba ZRC SAZU, 2015), 29

Darja Koter, Slovenska glasba 1848-1918 (Ljubljana: Študentska založba, 2012), 152-153.

10 The activities of predominantly well-educated Czech musicians were already of utmost importance in the music culture and education of the first half of the 19th century in Slovenia (Josef Mikš, Franc Sokol, Jan Slavik). Weiss, "Slovenian music history'," 80.

11 Anton Nedvěd (1829-1896), Czech conductor, composer and music teacher, lived in Ljubljana since 1856. He was Director of the Philharmonic Society (1858-1883), a teacher at the public music school (from 1859), and also taught at a secondary school and a semenary. Anton Foerster (1837-1926), Czech composer, organist and pianist, studied law and music in Prague. Since 1876 he worked in Ljubljana. As a choirmaster of the National reading society in Ljubljana, he felt a lack of musical knowledge of choir singers, what was an incentive for publishing of a textbook Kratek navod za pouk v petji $(1867,1869)$. He also established the Organ School in Ljubljana in 1877. Darja Koter, Slovenska glasba 1848-1918, 91-92, 96-98.

12 Jernej Weiss, Češki glasbeniki v 19. in na začetku 20. stoletja na Slovenskem (Maribor: Litera: Pedagoška fakulteta Maribor, 2012), 424-468.

13 Maruša Zupančič, Razvoj violinske pedagogike in šolstva na Slovenskem od začetka 19. stoletja do začetka druge svetovne vojne (Ljubljana: Znanstvena založba Filozofske fakultete Univerze v Ljubljani, 2013), 49-50, https://www.dlib.si/stream/ URN:NBN:SI:DOC-Q7AZJ2DJ/324e5af4-62dd-4660-8f4b-3f500e78e165/PDF.

14 "Glasbeno izobraževanje," Ministrstvo za izobraževanje, znanost in šport, accessed October 25, 2018, http://www.mizs.gov.si/ si/delovna_podrocja/direktorat_za_predsolsko_vzgojo_in_osnovno_solstvo/glasbeno_izobrazevanje/. 
Monarchy. The society, which three decades later also founded an orchestra, played an important role in the musical life of the broader environment. The first important milestone in the development of music education was the creation of the first schooltype institution, the Russian Emperor Maria Alexandrovna Girls Institute (Djevojački institut ruske carice Marije Aleksadrove) in Cetinje, the then capital of Montenegro. The Institute was intended for the general education of girls. However, music education, which focused on acquisition of abilities, skills and knowledge in singing, music theory, violin and piano, had an important role in it. As the institute operated under the patronage of Maria Alexandrovna, the Empress of Russia (1824-1880), until 1913, its programmes and syllabi were in line with those of the publically recognised Russian institutions of the period. The first public music school in Montenegro was established in 1936 in the then capital Cetinje. Only after World War II, a secondary music school was opened there as well. However, its seat was then transferred to Kotor in 1947. Here, a private music school, the Vida Matjan Music School, established in 1945 , operated alongside the public one. In 1947, the private music school was merged with the newly established state music school which was managed by the Slovene musician and teacher Vida Matjan until she retired in 1969. ${ }^{15}$ Vida Matjan, born Hribar (1896 1993), studied piano with the Slovene concert pianist and piano teacher Anton Trost at the Glasbena matica in Ljubljana where she concluded her studies in 1914. She continued at the music academy in Vienna. However, with the breakout of World War I, she was forced to interrupt her studies and returned to Ljubljana. In 1930 she moved to Belgrade with her husband. There she continued with her studies with professor and composer Emil Hajek and concluded in 1935. However, she could only obtain a higher-education diploma, as there was no academy in the region at that time. Vida Matjan spent the first part of her professional life in Belgrade. With the beginning of World War II, in 1941, she moved to Kotor permanently, together with her husband. With her musical and pedagogic talent, enthusiasm and vigour, she left a deep and lasting impression in the Montenegrin music education. She passed her versatile talent on to her students, skilfully combining the spheres of music, ballet and acting. For the purposes of the music school, she created eight musical tales, the most successful of which was A Frantic Night in the Woods (Besana šumska noč), to a text by Miloš Milošević. Her work was already recognised during her lifetime, while today the music school in Kotor is named after her. ${ }^{16}$

In 1946, a music school also opened in Podgorica. ${ }^{17}$ A decade later, in 1958, it was followed by the Secondary Music School, which in 2005 changed its name into Vasa Pavić Artistic School for Music and Balley (Umjetnička škola za muziko i balet Vasa Pavić), under which it still operates today. It provides primary and secondary music education and primary-level ballet. For many years, a Slovene music teacher Rudolf Zakrajšek (1915-1994), ${ }^{18}$ was the principal, and under his leadership the school achieved many

15 Bogojević Martinovič, "Views," 307.

16 Irena Gantar Godina, "Žensko znanstveno delo je za človeško družbo namreč brez vsake koristi...: slovenske izobraženke in umetnice med ožjo in širšo domovino (do 1921)," Dve domovini, 30 (2009): 166-167.

17 After WWII, in 1946, Podgorica was renamed Titograd and assumed the role of the capital city which it took over from Cetinje. In 1992, following a referendum, the city's name was changed back to Podgorica.

18 Rudolf Zakrajšek, a Slovene pedagogue and conductor, was born in Trebnje. After his study of composition, conducting and 
results and successes. Compared to the Ljubljana Music Academy (1939), the Music Academy in Montenegro, an equivalent institution with the purpose of educating home musicians and developing higher-level music education, was established rather late, in 1980. Until then, future professional musicians from Montenegro studied in the broader region of former Yugoslavia, particularly in Belgrade, Zagreb and Sarajevo. According to Bogojević Martinović, there are currently 14 state-owned music schools in Montenegro and 1 private. ${ }^{19}$

A historical overview shows that in the two countries, music education within music schools occurred at different points in history. In Slovenia, the first public music school was established in 1816. In Montenegro, on the other hand, an equivalent one opened its doors in 1936, while before that period, music education was provided as part of the general education programmes. Analysis proved that two Slovene musicians and teachers worked in Montenegro and made considerable contributions to the development of education in the Montenegrin music schools. There are many aspects of their work as music teachers still to be researched. The same goes for the potential influence of their own musical qualifications on the development of didactic concepts in Montenegro. The fact that Vida Matjan received her elementary music education in the Glasbena matica in Ljubljana, opens up the question whether the Slovene concept of music education was perhaps transferred into the Montenegrin environment, and if so, how.

\section{Contemporary Music School Education in Slovenia and Montenegro}

In Slovenia and in Montenegro, the music education systems in place include all educational levels - primary, secondary and tertiary. In both systems, the duration of educational programmes coincides at the secondary ( 4 years) and tertiary ( 5 years: $3+2$ ) levels, while primary-level education lasts 10 years in Slovenia and 9 years in Montenegro.

In both countries, primary music schools are included in the broader context of elementary general education. ${ }^{20}$ Both systems also include music as well as dance programmes. In the following paragraphs, this paper focuses on music programmes in primary music schools, making comparisons between the two countries. Enrolment in music schools is available to all children and teenagers who wish to learn an instrument

double bass at the Music academy in Belgrade, he was a professor at the Secondary music school Stanković in Belgrade. He continued his 40-years-long pedagogic activity in Montenegro at the Secondary music school in Kotor, where he taught harmony and contrapunct, as a director of the Vasa Pavić Primary Music School in the then capital Titograd and lectured music education methods at the Academy of Music. He was the founder of the Society of music school in Montenegro, one of the founder of Association of music pedagogues and a president of the Society of composers in Montenegro. He strived for the application of the contemporary principles in music education and he contributed to a higher quality of the overall development of music school education in Montenegro. Osebni arhiv Zorana Zakrajška, "Crnogorski Slovenac," accessed September 27, 2018.

19 Bogojević Martinovič, "Views," 308.

20 "Zakon o osnovnom obrazovanju i vaspitanju v Crni Gori," Službeni list Republike Crne Gore, br 64/2002, 49/2007, Sl. list CG, br. 45/2010, 40/2011 - dr. zakon i 39/2013, accesed October 25, 2018, https://www.google.com/search?q=ZAKON+O+OSNOV NOM+OBRAZOVANJU+I+VASPITANJU\&ie $=u t f-8 \& o e=u t f-8 \& c l i e n t=$ firefox-b.

"Osnovno šolstvo v Sloveniji," Ministrstvo za izobraževanje, znanost in šport, accessed September 10, 2018.

http://www.mizs.gov.si/si/delovna_podrocja/direktorat_za_predsolsko_vzgojo_in_osnovno_solstvo/osnovno_solstvo/.

"Glasbeno izobraževanje," Ministrstvo za izobraževanje, znanost in šport, accessed October 25, 2018, http://www.mizs.gov.si/ si/delovna_podrocja/direktorat_za_predsolsko_vzgojo_in_osnovno_solstvo/glasbeno_izobrazevanje/. 
and successfully pass an entrance exam, showing an adequate level of development of elementary musical abilities. The main objectives in both systems are to impart positive attitude towards music and culture to children and develop their musical abilities, skills and knowledge to a level necessary for a quality amateur musical activity or to proceed to secondary music education. In both countries, music school fees are subsidised from the state budget, while parents must cover the material costs of the education. The Slovene primary music school system is regulated by the Music Schools Act, ${ }^{21}$ implementing regulations and rules, and has as a broader legal basis also the UN Convention on the Rights of the Child as well as the Weimar Declaration, adopted by the EMU members in 1999. ${ }^{22}$ Elementary music school education in Montenegro, on the other hand, has not been regulated so far. This lack of regulation and the situation caused by it manifested the need for the Music Schools Rules, which is currently still under preparation and will clearly determine the pursuit of activities in primary music schools.

Even though music school education is not compulsory in either country, as opposed to general primary schools, it is still part of the broader primary education framework, which is reflected in the matching organisation and structure. Consequently, bigger changes in the general primary school system cause changes and tendencies to adapt in music schools as well. In both countries, it is possible to observe how the latest curricular reforms in the general education system (carried out in the 1990s in Slovenia and in the 2000s in Montenegro) triggered changes also in music schools. The shift from an eight- to a nine-year primary school in Slovenia was followed also in Montenegro as an example of a quality primary school system reform. The process of the first curricular reform in the Montenegrin general school system, introduced after Montenegro gained its independence in 2006, was carried out with professional support of and in international cooperation with the Republic of Slovenia which steered the structure and content of the changes made in the field of music education in primary school. In line with the changed structure and content of primary education, which also moved the age limit at which children enter primary school one year ahead, to 6 , several systemic, organisational and content-related changes were introduced in music schools as well. In Slovenia, the reformed music programmes were implemented in two stages: the pre-school programmes in the school year 2002/03 and music and dance programmes in the school year 2003/04, ${ }^{23}$ while in Montenegro, adapted and reformed curricula for elementary music and ballet education were prepared in 2007.24 The Slovene curricular reform introduced three new programmes to primary music school: Preschool Music Education (a 1-year programme for 5-year-old children), Music Preparatory (a 1-year programme for 6-year-old children) and Dance Preparatory (a 3-year programme enrolling children at the age of 6). After the reform, the Music and Dance programmes are structurally and organisationally divided into two parts: lower

21 "Zakon o glasbenih šolah," Uradni list RS, št. 81/2006, accessed October 25, 2018, https://www.uradni-list.si/glasilo-uradni-list-rs/ vsebina?urlid=200681\&stevilka=3536.

22 Franci Okorn, Izobraževanje v Sloveniji za 21. stoletje. Koncepcija razvoja glasbenega in baletnega izobraževanja (Ljubljana: Zavod Republike Slovenije za šolstvo in šport, 1991), 37-39.

23 Branka Rotar Pance, "Slovenian Music Education between Tradition and Challenges, in New Perspectives in Music Education in Slovenia, ed. Olga Denac (New York: Nova Science, 2012), 5-8.

24 Bogojević Martinovič, "Views," 309. 
level (6 years) and upper level (2 years). The curriculum of the Music programme has been enriched with several new instruments, such as the organ and folk instruments (zither, diatonic button accordion and tambura). The subject Music Theory was also upgraded with a new subject Solfeggio. Another new subject introduced as a result of the reform was the Chamber Music. ${ }^{25}$

One major change the curricular reform in Montenegro brought about was the prolongation of primary music school education from 7 to 9 years. The syllabi for individual instrument lessons as well as for group lessons, prepared in 2007, were adapted for younger children, so that after the reform they can enrol already at the age of 6 . The structure of the Montenegrin primary music school education matches that of the general primary school education and arranged into trienniums. Confirmation of the syllabi was gradual, with the last of them confirmed only in 2016, which caused many dilemmas in the teaching practice as to whether to plan and implement the contents according to the previous (old) programme or the new one. As the choice between the two programmes was up to each individual school, the new programmes, introduced by the Montenegrin curricular reform, have never really come to life. In the school year 2018/19, new syllabi have become effective and all Montenegrin music schools have to implement their programmes, general and operational objectives accordingly.

Contrary to Montenegro, in Slovenia evaluation of the newly introduced programmes and syllabi took place during this intermediary period. Monitoring and reviewing the situation after the introduction of novelties continued until 2010, when the curriculum and syllabi were complemented in line with the analysis carried out and its findings, as well as with the needs expressed by the pedagogic practice. With some instruments, namely flute, clarinet, oboe, bassoon, saxophone, viola, brass instruments and percussions, the education was extended from 6 to 8 years.

As regards the orchestras, guitar and jazz orchestras and Orff groups were added to the already existing string, symphonic, accordion and tambura orchestras. Furthermore, Choir was reintroduced as a subject and children can attend it from the first year on. ${ }^{26}$

In 2017, preparations of new proposals for improvements of the programme Music and Dance have started in connection with the preparation of descriptive assessment criteria and minimum standards. The efforts to give meaning to numeric marks are oriented towards the creation of assessment scales from 1 to 5 . In musical projects which became well established and permanent part of Slovene music schools, the need arouse to monitor and evaluate students' musical progress at various stages of planning, preparation and implementation of the projects. Project activities support the possibility to evaluate the motivation level and the development of students in the creative process and in the final execution of the planned project. ${ }^{27}$

25 Martina Valant, "Pouk v glasbeni šoli po šolski prenovi," in Javno glasbeno šolstvo na Slovenskem. Pogledi ob 200-letnici. Glasbenopedagoški zbornik Akademije za glasbo v Ljubljani 25 (2016): 219-225.

26 Valant, "Pouk," 223-225.

27 "RPS za pripravo izvedbenih modelov za preverjanje in ocenjevanje ustvarjalnosti na glasbenih šolah," Posodobitve učnih načrtov v glasbenih šolah, Letni delovni načrt Zavoda za šolstvo RS, 2018. 


\section{Slovene and Montenegrin Music School Curricula}

This chapter presents the primary music school curricula in Slovenia and Montenegro. It gives an overview of similarities and differences in the educational structure of the two systems.

In Slovenia, students start with individual instrumental lessons and group lessons of Music Theory at the age of 7. Enrolment in primary music school is of a selective nature, i.e. students have to pass an entrance exam, while the two preschool programmes are not selective and are open to everybody. The Music programme consists of individual instrumental lessons and group lessons of Music Theory and Solfeggio. The programme can last for 4,6 or 8 years, depending on the chosen instrument and the student's age at enrolment, and is divided into two levels: lower and upper. At the lower level, students have two 30-minute individual instrumental lessons per week, while students of the upper level have two 45-minute lessons per week. Once a week students also have to attend Music Theory (lower level) or Solfeggio (upper level), which lasts 45, 60 or 90 minutes, depending on the number of students in the class. The reform introduced a new compulsory subject - Chamber Music, which is held once a week and lasts 60 minutes. In general, students start attending Chamber Music in the $5^{\text {th }}$ class; however, students of harp and guitar start in the $7^{\text {th }}$ class, students of singing in the $3^{\text {rd }}$ and students of the organ in the $4^{\text {th }}$. All students have to attend either a choir or an orchestra. Music schools can have various kinds of orchestras: string, wind, symphonic, accordion, tambura, and, since 2010, also guitar or jazz orchestras. The subject Orchestra is held once a week for 90 minutes, except in the case of symphonic, jazz and guitar orchestras, where each lesson lasts for 135 minutes. Students start playing in orchestras in the $4^{\text {th }}$ (students of woodwinds, brass, percussions, tamburas and double base) or $5^{\text {th }}$ (students of violin, viola, cello, harp, guitar, accordion) class. With harp and tambura, the subject is compulsory only if there is a suitable orchestra for the respective instrument in the school. In 2010, choir was reintroduced as a subject. It is scheduled twice a week, and is intended for all children from the 1st class on who cannot participate in an orchestra due to the specifics of their chosen instrument. ${ }^{28}$

In the Montenegrin system, students enrol in music school at the age of 6, when they attend the first class of Music Preparatory - Orff Instruments (Muzička početnica - Orffov instrumentarij) which offers intense and systematic development of abilities, skills and knowledge, directs and motivates for further education in connection with the chosen instrument. ${ }^{29}$ In terms of general and operational objectives and knowledge standards, the subject Music Preparatory - Orff Instruments corresponds to the Slovene programme Music Preparatory which is also intended for 6-year olds. Contrary to the Slovene programme, enrolment to the Montenegrin Music Preparatory is subject to a successfully passed entrance exam. Thus, in Montenegro access to music school is selective right from the beginning, while the Slovene system offers the possibility of a year of education and preparation for the entrance exam for the Music programme. In

28 Valant, "Pouk," 222-224.

29 "Muzička početnica - Orffov instrumentarijum. Nastavni program za prvi razred reformisane muzičke škole (2009)," Podgorica: Ministarstvo prosvjete i nauke, Nacionalni savjet obrazovanja. 
the Montenegrin system, 7-year-old students who finish the $1^{\text {st }}$ class of Music Preparatory, continue with their education uninterruptedly. They proceed to the $2^{\text {nd }}$ class of the group subject called Solfeggio with Music Theory (Solfedo sa teorijom muzike) and start learning the instrument of their choice. The structure of the Montenegrin primary music school education coincides with that of their 9-year general primary school and is divided into triennia. Students who start their education at 6, receive their leaving certificate after having concluded the second triennium, i.e. after 6 years of education. Highly talented students continue go on to the third triennium as potential candidates for further music education at the secondary school level. At all levels of music education, instrumental lessons are carried out individually, as 45-minute lessons which are held twice a week. Solfeggio with Music Theory starts in the $2^{\text {nd }}$ class where it is taught once a week for 45 minutes, while from the $3^{\text {rd }}$ to the $9^{\text {th }}$ class students have 45-minute Solfeggio lessons twice a week. In the second triennium, students attend a choir or orchestra, to which two 45-minute lessons are dedicated a week. Adopted in 2016, the syllabi for the third triennium of the Montenegrin music schools focus on preparing students for further education at the secondary level. In the third triennium the number of choir or orchestra lessons increases from two to three per week, and an optional subject is added once a week. The functioning of orchestras of various types or choirs is connected with the number of students and personnel available at individual schools; based on these conditions, these group subjects can either be carried out or not. The introduction of additional lessons into the third triennium gave rise to many questions about positive influence of a high number of weekly lessons (8) on an individual's musical development on one hand and the effects of the burden of music school in relation to other obligations. Consequently, these questions showed the need for a revision of the curriculum which went on until the school year 2018/19. ${ }^{30}$ Table 1 shows the number of years of study per individual instruments and group theoretical subjects in primary music school in Slovenia and Montenegro.

As it is evident from Table 1, there is a difference between the Slovene and Montenegrin systems in the lower and upper level cycles. While in Montenegro, the lower-level education comprises 3 to 5 study years and the upper-level 3 years, in Slovenia, the lower level can last from 4 to 6 (2 years in case of the organ, with students previously studying piano for 4 years) and the upper level 2 years. The upper level comprises 2 years of study in Slovenia and 3 years in Montenegro. In both countries, the upper level offers students the possibility to prepare for entrance exams and continue their music education in secondary schools, which leads towards a professional career. In this respect, the Montenegrin highly talented students are in advantage over their Slovene counterparts, since their preparation is a year longer. Another difference is the fact that the lower level education in Slovenia is one year longer than in Montenegro. Each of the two organisational structures described brings advantages as well as disadvantages: the Slovene concept is oriented towards attracting the primary school population to and keeping it in primary music education for a longer period of time, while the Montenegrin systems focuses more on highly talented students, encouraging and

30 Bogojević Martinović, "Views," 309. 
K. ZADNIK・ PRIMARY MUSIC SCHOOL EDUCATION

\begin{tabular}{|c|c|c|}
\hline Curriculum & Number of study & ears \\
\hline Preschool education & Slovenia & Montenegro \\
\hline Preschool music education & 1 year (5-year-olds) & / \\
\hline Music Preparatory & 1 year (6-year-olds) & 1 year (6-year-olds) \\
\hline $\begin{array}{l}\text { Individual instrumental lessons/ } \\
\text { Music Theory/Solfeggio/ Solfeggio } \\
\text { with Music Theory }\end{array}$ & $\begin{array}{l}\text { Lower/upper } \\
\text { level, together }\end{array}$ & $\begin{array}{l}\text { Lower/upper level, } \\
\text { together }\end{array}$ \\
\hline Piano, violin, cello & $6+2=8$ & $5+3=8$ \\
\hline Viola & $6+2=8$ & $3+3=6$ \\
\hline Double Bass & $4+2=6$ & $3+3=6$ \\
\hline $\begin{array}{l}\text { Woodwinds } \\
\text { (flute, clarinet, saxophone, oboe, } \\
\text { bassoon) }\end{array}$ & $6+2=8$ & $3+3=6$ \\
\hline Recorder & $6+2=8$ & 1 \\
\hline $\begin{array}{l}\text { Brass instruments } \\
\text { (trumpet, trombone, horn) }\end{array}$ & $6+2=8$ & $3+3=6$ \\
\hline $\begin{array}{l}\text { Baritone, tuba, other conical } \\
\text { instruments }\end{array}$ & $6+2=8$ & / \\
\hline Percussion & $6+2=8$ & $3+3=6$ \\
\hline Harp & $6+2=8$ & $5+3=8$ \\
\hline Guitar & $6+2=8$ & $5+3=8$ \\
\hline Accordion & $6+2=8$ & $5+3=8$ \\
\hline Singing & $4+2=6$ & $\begin{array}{l}3 \text { years } \\
\text { (3rd triennium) }\end{array}$ \\
\hline Organ & $2+2=4$ & $\begin{array}{l}3 \text { years } \\
\text { (3rd triennium) }\end{array}$ \\
\hline $\begin{array}{l}\text { Folk instruments } \\
\text { (zither, diatonic accordion) }\end{array}$ & $4+2=6$ & / \\
\hline Tambura/Mandolin & $4+2=6$ & $3+3=6$ \\
\hline $\begin{array}{l}\text { Music Theory+Solfeggio/Solfeggio } \\
\text { with Music Theory }\end{array}$ & $6+2=8$ & $5+3=8$ \\
\hline
\end{tabular}

Table 1: Duration of education in preschool programs, instruments and musical-theoretical subjects in Slovenia and Montenegro. 
steering them to further music education with the aim of fostering professional career in music. As regards the total years of study, the comparison between the two concept shows that students can study for 6 to 8 years. Table 1 shows that the Slovene system offers one pre-school programme for young children more than the Montenegrin, accepting students already at the age of 5 .

In Montenegro, there have been many polemics and discussion about how to keep the motivation of students who cannot pass directly from the Music Preparatory to instrumental lessons due to specific characteristics of some instruments which require a higher level of development of physical abilities than those in 7-year olds. These gaps are evident also in Table 1 at viola, woodwinds, brass instruments and percussions. With these instruments, students have to wait for two years before they can start learning them. Teachers in Montenegro have been looking for suitable solutions for the disadvantaged students and ways to keep their interest and motivation to stay in music school. ${ }^{31}$ In Slovenia, the described problem is solved by using smaller versions of the instruments concerned. The music industry market offers instruments ergonomically adapted to the physical characteristics of younger children, which enables them to start learning those instruments already at the age of $6 .{ }^{32}$

The new Slovene music school programmes provide two versions of the subject Music Theory: version A for students between 7 and 9, and version B for students from 10 years on. Until the school year 2018/19 the problem of including older and younger students in the Montenegrin system was solved by using the previous (old) programme from 1998, ${ }^{33}$ for students who started learning an instrument at the age of 8 or 9 , and the new programmes, which were gradually confirmed from 2009 to 2016, for younger students. The results of the ten-year evaluation of the new curricula have become effective with the school year 2018/19.

\section{Conclusion}

Contemporary concepts of primary music school education are linked to the recent and farther past developments in the national systems. Even though Montenegro and Slovenia used to pertain to a common geopolitical area, their systems of primary music school education show distinctive characteristics in their past and present development. The origins of institutionalised music education appeared in the beginning of the $19^{\text {th }}$ century in the Slovene territory, with the first public music school near the Ljubljana normal school, in year 1816, while the first public music school in Montenegro was established in the first half of the $20^{\text {th }}$ century, in 1936, in the then capital Cetinje. After World War II, the influences of the then Croatian and Serbian music teachers are found in both regions, in the former common state Yugoslavia. In the same period,

31 "Okrogla miza," Muzičko obrazovanje u Crnoj Gori: Perspektive i izazovi, Cetinje: Ministarstvo za kulturo. 9. 11. 2017.

32 Igor Krivokapič, "Novi helikoni in nove možnosti," Glasba v šoli in vrtcu 18, št. 1/2 (2014): 43-44.

Špela Ramšak, “Dejavniki izbire inštrumenta v glasbeni šoli,” (mag.delo, Univerza v Ljubljani, Akademija za glasbo, 2017), 6-13.

33 "Program za nastavu solfeđa u osnovnim muzičkim školama u Crnoj Gori. Pripremni razred, 1. do 6. razred, 1998." Podgorica Ministarstvo prosvjete i nauke Crne Gore, Odjelenje za razvoj i programiranje. 
there are also found some influences of the Slovene music teachers in Montenegro who left considerable contributions to the development of education in the Montenegrin music schools. Regarding of their musical qualifications, also received within the Slovene concept, there is a question of the potential implementation of Slovene music didactic concept in the Montenegrin music-school education.

Contemporary music-school education at the primary level lasts for 10 years in Slovenia, and 9 years in Montenegro. The Slovene primary music school in its structure supports music education in the earliest life period, by 5-year-olds, in the Montenegrin music school system the enrolment is enabled for 6-year-olds. In the Slovene system, children can develop musical abilities, skills and knowledge during two years, while in the Montenegrin system only one year. In both systems, the aim of the preschool programmes is to prepare children for the further music education - playing the instrument. In both curricula, there are similarities at the primary level education regarding instrumental subjects, while the Slovene curricula includes some more woodwind (recorder) and brass instruments (baritone, tuba, other conical instruments). Last curricular reform in both countries encouraged the implementation of folk instruments. This novelty is a reflection on the recent increasing trend of globalization. Both countries are aware of its culture's roots and musical heritage as a basic starting point in music teaching and learning. The comparison of structure of both systems shows differences in duration in the lower and upper level. While the Slovene concept is oriented to keeping primary school population in primary music school in longer period of time, the Montenegrin concept focuses more on talented students. The observation in the Slovene music-school practice, although the mentioned aspect, shows on a greater tendencies to discover and encourage musical talented students, instead of stimulating a positive attitude towards music in young population in general. Due to the constantly changing society, music school education in both systems is in front of a challenge how to encourage a development of a creative and holistic (musical) personality as a response on the current needs of the contemporary society. This issue is already in a focus of discussion for improvement of instrumental and Music Theory lessons in Slovenia. Preparations of new proposals for improvement of the programme Music and Dance have started in connection with formulation of descriptive assessment criteria and minimum standards as well as implementation models for planning and realisation of creativity in music school. ${ }^{34}$ In Montenegro, the evaluations of the new syllabi for group and instrumental lessons have recently been concluded and the syllabi have come into effect in the school year 2018/2019. The Montenegrin music-school system is in front of the monitoring and observation of the prepared syllabi in the school practice and its quality responses on needs of the society, culture and art.

In conclusion, we would like to point out that the common view of experts from both systems who, besides quality curricula and musical programmes, underlined the important role of the teacher, who must be able, based on their own strong competences and creativity, to stimulate and keep a student motivation to learn music, and

34 "RPS za pripravo izvedbenih modelov za preverjanje in ocenjevanje ustvarjalnost na glasbenih šolah," Posodobitve učnih načrtov $v$ glasbenih šolah, Letni delovni načrt Zavoda za šolstvo RS, 2018.

"Okrogla miza," 9. 11. 2017. 
create a stimulated environment with encouragements that will maintain a positive attitude towards music, and contribute to holistic personality in general.

\section{Bibliography}

Bogojević Martinović, Jelena. "Views on the Elementary Music Education in Montenegro and Slovenia." Javno glasbeno šolstvo na Slovenskem. Pogledi ob 200-letnici. Glasbenopedagoški zbornik Akademije za glasbo v Ljubljani 25 (2016), str. 305-316.

Cigoj Krstulović, Nataša. Zgodovina, spomin, dediščina: ljubljanska Glasbena matica do konca druge svetovne vojne. Ljubljana: Založba ZRC SAZU, 2015.

Denac, Olga. Glasba pri celostnem razvoju glasbene osebnosti. Ljubljana: Zavod RS za šolstvo, 2002.

EMU 2015. "Statistical information about the European Music School Union." Accessed October 25, 2018. http://www.musicschoolunion.eu/wp-content/uploads/2017/09/ EMU-Statistics-2015-08.09.2017.pdf.

Gantar Godina, Irena. "Žensko znanstveno delo je za človeško družbo namreč brez vsake koristi...: slovenske izobraženke in umetnice med ožjo in širšo domovino (do 1921)." Dve domovini: razprave o izseljenstvu, 30 (2009): 155-174. http://www.dlib. si/details/URN:NBN:SI:doc-RKDNCNGG.

Kopačin, Barbara. "Medsebojna povezanost inteligentnosti, glasbenih aktivnosti in družinskega okolja pri devetošolcih.” Revija za elementarno izobraževanje 7 , št. 2 (2014): 81-96. http://www.pef.um.si/content/Zalozba/clanki_2014_letnik7\%20_ stev_2/REI\%207\%202\%20web\%20cl\%205.pdf.

Koter, Darja. Slovenska glasba 1848-1918. Ljubljana: Študentska založba, 2012.

Krivokapič, Igor. "Novi helikoni in nove možnosti." Glasba v šoli in vrtcu 18, št. 1/2 (2014): 41-45.

Ministarstvo prosvjete i nauke Crne Gore, Nacionalni savjet obrazovanja. "Muzička početnica - Orffov instrumentarijum. Nastavni program za prvi razred reformisane muzičke škole." Podgorica, 2009.

Ministarstvo prosvjete i nauke Crne Gore, Odjelenje za razvoj i programiranje. "Program za nastavu solfeđa u osnovnim muzičkim školama u Crnoj Gori. Pripremni razred, 1. do 6. razred." Podgorica, 1998.

Ministrstvo za izobraževanje, znanost in šport. "Glasbeno izobraževanje." Accessed October 25, 2018. http://www.mizs.gov.si/si/delovna_podrocja/direktorat_za_predsolsko_vzgojo_in_osnovno_solstvo/glasbeno_izobrazevanje/.

Ministrstvo za izobraževanje, znanost in šport. "Osnovno šolstvo v Sloveniji." Accessed September 10, 2018. http://www.mizs.gov.si/si/delovna_podrocja/direktorat_za_ predsolsko_vzgojo_in_osnovno_solstvo/osnovno_solstvo/.

Muzičko obrazovanje u Crnoj Gori: Perspektive i izazovi. "Okrogla miza." Cetinje: Ministarstvo za kulturo. 9. 11. 2017.

Okorn, Franci. Izobraževanje v Sloveniji za 21. stoletje. Koncepcija razvoja glasbenega in baletnega izobraževanja. Ljubljana: Zavod Republike Slovenije za šolstvo in šport, 1991. 
Osebni arhiv Zorana Zakrajška. "Crnogorski Slovenac,” Dnevni list Pobjeda. Accessed September 27, 2018.

Posodobitve učnih načrtov v glasbenih šolah. "RPS za pripravo izvedbenih modelov za preverjanje in ocenjevanje ustvarjalnosti na glasbenih šolah.” Letni delovni načrt Zavoda za šolstvo RS, 2018. http://www.ibe.unesco.org/Countries/WDE/2006/CENTRAL_and_EASTERN_EUROPE/Montenegro/Montenegro.pdf.

Ramšak, Špela. "Dejavniki izbire inštrumenta v glasbeni šoli." Magistrsko delo, Univerza v Ljubljani, Akademija za glasbo, 2017.

Rotar Pance, Branka. "Slovenian Music Education between Tradition and Challenges." In New Perspectives in Music Education in Slovenia, edited by Olga Denac. New York: Nova Science, 2012, 1-17.

Sicherl Kafol, Barbara. Celostna glasbena vzgoja. Srce, um, telo. Ljubljana: Debora, 2001 Službeni list Republike Crne Gore, br 64/2002, 49/2007, Sl. list CG, br. 45/2010, 40/2011 - dr. zakon i 39/2013. "Zakon o osnovnom obrazovanju i vaspitanju v Crni Gori." Accessed October 25, 2018. https://www.google.com/search?q=ZAKON+O+OSNOVN OM+OBRAZOVANJU+I+VASPITANJU\&ie=utf-8\&oe=utf-8\&client=firefox-b.

Smolej Fritz, Barbara. "Razvoj vidikov glasbenih sposobnosti, ki jih meri Bentleyev test." Psihološka obzorja 9, št. 1 (2000): 91-106.

Uradni list RS, št. 81/2006. "Zakon o glasbenih šolah." Accessed October 25, 2018, https://www.uradni-list.si/glasilo-uradni-list-rs/vsebina?urlid=200681\&stevilka=3536.

Valant, Martina. "Pouk v glasbeni šoli po šolski prenovi." Javno glasbeno šolstvo na Slovenskem. Pogledi ob 200-letnici. Glasbenopedagoški zbornik Akademije za glasbo v Ljubljani 25 (2016): 217-236.

Weiss, Jernej. “'Slovenian music history' or 'History of music in Slovenia'? With respect to the Role of Czech Musicians on Musical Culture in Slovenia in the 19th and the beginning of the 20th century." Muzikološki zbornik 45, št. 1 (2009): 75-88. http:// www.dlib.si/?URN=URN:NBN:SI:DOC-V3DCAODM.

Weiss, Jernej. Češki glasbeniki v 19. in na začetku 20. stoletja na Slovenskem. Maribor: Litera: Pedagoška fakulteta Maribor, 2012.

World Data on Education 6th edition (2006/07). "Principles and general objectives of education Montenegro.” Accessed October 25, 2018.

Zadnik, Katarina. "Razvoj ritmičnega in melodičnega posluha pri 8-letnih učencih v glasbeni šoli.” Dok. dis., Univerza v Ljubljani, Akademija za glasbo, 2011.

Zupančič, Maruša. Razvoj violinske pedagogike in šolstva na Slovenskem od začetka 19. stoletja do začetka druge svetovne vojne. Ljubljana: Znanstvena založba Filozofske fakultete Univerze v Ljubljani, 2013. https://www.dlib.si/stream/URN:NBN:SI:DOCQ7AZJ2DJ/324e5af4-62dd-4660-8f4b-3f500e78e165/PDF. 


\section{POVZETEK}

V evropskem prostoru sledimo raznolikim zakonskim, sistemskim in organizacijskim vidikom urejenosti na osnovni ravni glasbenega šolstva. Komparativna analiza slovenskega in črnogorskega koncepta glasbenega šolstva je pokazala na njune svojstvene razvojne poti od 19. stoletja do sodobnosti. Prva slovenska javna glasbena šola začne delovati na začetku 19. stoletja, formalno glasbeno izobraževanje $\mathrm{v}$ črnogorskem prostoru pa izhaja iz 2. polovice 19. stoletja. $V$ času po drugi svetovni vojni so bili prisotni v nekdanji skupni državi vplivi tedanjih hrvaških in srbskih glasbenih pedagogov, medtem ko sledimo v Črni gori tudi vplivom nekaterih slovenskih glasbenih pedagogov, ki so delovali na tem ozemlju. Temeljni cilj obeh sodobnih sistemov je vzgojiti pozitivni odnos do glasbene umetnosti in kulture in razviti funkcionalno glas- beno pismenost pri individualnem inštrumentalnem pouku in skupinskih glasbeno-teoretičnih predmetih. Zadnja kurikularna prenova, po letu 2000, je vnesla sistemske in vsebinske spremembe na ravni predmetnikov in učnih načrtov. Izrazita sprememba se je pojavila v obsegu trajanja glasbenega izobraževanja: $\mathrm{v}$ slovenskem prostoru ta traja 10 let, v črnogorskem prostoru pa 9 let. Slovenski sistem glasbenega izobraževanja omogoča vstop v glasbeno izobraževanje pri 5-ih letih, črnogorski sistem pri 6-ih letih. V predmetnikih obeh glasbeno-izobraževalnih sistemov so vključeni glasbeno-teoretični predmeti, ki potekajo v skupinski učni obliki, in predmeti različnih inštrumentov, ki potekajo $\mathrm{v}$ individualni učni obliki. Z razliko od črnogorskega koncepta so v predmetnik slovenske glasbene šole vključeni še nekateri inštrumenti iz skupine pihal (kljunasta flavta) in trobil (bariton, basovska krilovka/tuba, druga konična trobila). 